Please do not remove this page

RMIT

UNIVERSITY

\title{
Unlocking the potential? Australia's digital strategy and major public libraries
}

McShane, Ian; Thomas, Julian

https://researchrepository.rmit.edu.au/esploro/outputs/9921858259901341/filesAndLinks?institution=61RMIT_INST\&index=null

McShane, I., \& Thomas, J. (2010). Unlocking the potential? Australia's digital strategy and major public libraries. Prometheus: Critical Studies in Innovation, 28(2), 149-163.

https://doi.org/10.1080/08109028.2010.496235

Published Version: https://doi.org/10.1080/08109028.2010.496235

Repository homepage: https://researchrepository.rmit.edu.au

(C) 2010 Taylor and Francis

Downloaded On 2023/04/26 19:58:28 +1000

Please do not remove this page 
Thank you for downloading this document from the RMIT Research Repository.

The RMIT Research Repository is an open access database showcasing the research outputs of RMIT University researchers.

RMIT Research Repository: http://researchbank.rmit.edu.au/

\section{Citation:}

McShane, I and Thomas, J 2010, 'Unlocking the potential? Australia's digital strategy and major public libraries', Prometheus: Critical Studies in Innovation, vol. 28, no. 2, pp. 149-163.

See this record in the RMIT Research Repository at:

http://researchbank.rmit.edu.au/view/rmit:19495

Version: Accepted Manuscript

Copyright Statement: (c) 2010 Taylor and Francis

Link to Published Version:

http://dx.doi.org/10.1080/08109028.2010.496235 
Unlocking the Potential? - Australia's Digital Strategy and Major Public Libraries

Ian McShane * \& Julian Thomas

Institute for Social Research,

Swinburne University of Technology

Mail H 53

PO Box 218

Hawthorn, Victoria

Australia 3122

Corresponding author:

imcshane@swin.edu.au

Ph 61392144352 


\title{
Unlocking the Potential? - Australia's Digital Strategy and Major Public Libraries
}

Ian McShane \& Julian Thomas

Swinburne University of Technology, Melbourne

\begin{abstract}
This article examines some implications for public libraries of the Australian government's 2009 strategy for the digital economy. Many countries have produced national digital strategies in recent years, but these key pieces of policy architecture have received little critical attention. The rhetorical framing of the Australian document indicates the shift of communication and information to the centre of economic policy. As such, it has particular significance for public libraries, as the major public information portals and cultural storehouses of liberal democracies. The strategy's emphasis on productivity and economic competitiveness, boosted by a proposed high-speed national broadband network, presents major opportunities for Australian libraries. However, libraries and other collecting institutions have voiced concern over assumptions that they can simply 'unlock' their collections and supply content for new broadband applications. In contrast to some other countries, the Australian strategy pays no attention to the profound implications for information integrity and cultural memory presented by the expansion of cultural and economic activity in the digital sphere. The challenge for public libraries, the article argues, is to explore ways that orthodox library responsibilities and new roles can be articulated in this evolving policy framework.
\end{abstract}

Keywords: digital economy, broadband, policy formation, public libraries, Australia.

\section{Introduction}

In July 2009 the Australian government released Australia's Digital Economy Future Directions (Department of Broadband, Communications and the Digital Economy, 2009; hereafter Future Directions), the most ambitious attempt yet by Australian policymakers to grapple with the social and economic transformations of digital communication technologies. Future Directions takes its place alongside - and implicitly positions itself against - digital strategies produced by many other nations within the past few years (WSIS Executive Secretariat, 2005; McDonald, 2006). These key pieces of national policy architecture have received little critical attention. The significance of Future Directions in current Australian policy is 
indicated by its whole-of-government brief and unequivocal rhetoric. Its sponsoring minister sets the tone by suggesting the document "...outlines those issues on which we must direct our attention today and in the near future to ensure that we are able to fully engage in the 21st century" (p.i).

Future Directions is evidence of the shift of communication and information to the centre of economic policy (Cawley and Preston, 2007; Given, 2009). In this light, digital strategies have particular significance for major public libraries - the chief public information portals and cultural storehouses of liberal democracies. This article examines the context and contents of Future Directions, with particular regard to its implications for major public libraries in Australia ${ }^{1}$. Statements on the importance of digital content for economic prosperity, cultural identity, citizenship and service delivery - Future Directions' core themes - resonate with long-standing library rationales, and recent statements about the role of libraries in a digitally connected world (National and State Libraries Australasia 2006, 2007; Missingham, 2009). However, the emphasis in Future Directions on productivity and economic competitiveness poses challenges for public libraries. The economic model sketched out in Future Directions sees small-to-medium enterprises (SMEs - firms with less than 200 employees) as the locus of growth and innovation. While the contours of the Australian economy - SMEs comprise $99 \%$ of Australian businesses - justify this focus, responses from libraries and the wider cultural sector voice concern over assumptions that cultural agencies can simply 'unlock' their collections and supply content for new broadband applications. Such assumptions illuminate a deeper concern that the library sector has slipped out of a direct policy line of sight, as the policy rhetoric has narrowed in recent decades from information society, through information economy, to digital economy.

Bringing this discussion into sharp focus in the Australian context is the recent announcement by the Australian national Labor government led by Kevin Rudd of a $\$ 43$ billion investment by a public/private consortium to construct a 100 megabit broadband network, connecting $90 \%$ of Australian homes, public institutions and business premises (Conroy, 2009). The projected capability of the National Broadband Network (NBN) offers major opportunities for libraries and other public cultural institutions to enhance access to collections and knowledge resources, to develop programs, and to build links with user communities. However, the network's capital costs and the Australian government's commitment to sell down its interest within five years of construction suggests the commercial pressures on the near strategic horizon. The question arises whether, and under what terms, investment will flow to public libraries to take advantage of these opportunities.

\footnotetext{
${ }^{1}$ Major public libraries are defined here as state (provincial) or national level public libraries with reference collections.
} 
This article begins by backgrounding the development of Future Directions, tracing its key external influences and its lineage within Australian policy formation. The research strategy involved analyzing a convenience sample of digital strategies released by six Organisation of Economic Cooperation and Development (OECD) member countries between 2002 and $2008{ }^{2}$, and a historical archive of Australian government policy papers on the information economy. An interpretivist framework, focusing on how meanings are constituted by actors (in this case, the agencies authoring the documents), was used to analyse these documents (Yanow and Schwart-Shea 2006). From this perspective, the significance of institutional and portfolio interests in setting strategic directions becomes apparent.

The article then examines the structure and dynamics of the digital economy as it is modelled in Future Directions. This section argues that the static representation of government, firms and the community as economic actors does not reflect fluid institutional roles in the emerging socio-economic spaces of the digital economy. But more troubling is Future Direction's lack of attention to the wider system-level implications of expanding activity in the digital sphere. We argue that public libraries can play a central role not simply as content providers, but in identifying and managing the cultural and economic transformations associated with digital technologies. Drawing on Nardi and O'Day's (1999) ecological metaphor, we set out an agenda for public libraries as key agents in a diverse, adaptive and sustainable information ecosystem. This view takes us beyond the economic focus of Future Directions to frame a more challenging assessment of Australia's high-speed broadband network as a locus of citizenship as well as consumption.

\section{Digital Strategies - the International Context}

The uses and management of digital technologies rapidly emerged as a multidimensional and global policy interest following the advent of the public internet in the mid-1990s. The concurrent production of national digital strategies within the past decade has several specific contexts: the World Summit on the Information Society (WSIS) 2003 and 2005 rounds (Klein, 2004), the liberalisation and harmonisation goals of the OECD (OECD 2006a), and trade negotiations involving intellectual property (Weiss et al, 2004). The rhetorical preference for "strategy" over "policy" can be traced to a WSIS agreement on the development of such documents, stressing inter-governmental planning and coordination. However, the use of strategy - with its game-theoretic orientation - also points to international competition within a broadly neoliberal environment (Pyati 2005).

Some sub-national governments were early movers in re-organising portfolios to reflect the emerging contours of the digital economy. For example, in 1998 the Victorian state government in Australia added Information Technology and Multimedia to the Treasury portfolio title. Similarly, supra-national bodies such as

\footnotetext{
${ }^{2}$ Australia, Canada, Ireland, New Zealand, Norway, United Kingdom.
} 
the European Union have framed digital strategies to support wider policy goals of economic liberalisation, active citizenship and cultural preservation (Commission of the European Communities, 2005). However, action has been most concentrated at national level. National governments have shifted from a largely regulatory telecommunications posture to a strategic one, as they set about the increasingly difficult task of reconciling borderless digital economic and cultural transactions with the physical and legal parameters of the nation-state.

Australia's policy outlook in this area mirrors that of several other small and medium sized cultural economies. Similar concerns about productivity and competitiveness, the promotion of e-government, participation and digital literacy, and the preservation of national culture inform strategies produced by Ireland (Forfas, 2002), Norway (Ministry of Modernisation, 2005), Canada (Library and Archives Canada, 2007), and New Zealand (Ministry of Economic Development, 2008). Different cultural and political traditions modulate the documents. For example, New Zealand's and Canada's commitment to biculturalism frame distinctive policy responses in those jurisdictions. Focussing on the policy development process though, shows the sensitivity of these strategies to the institutional circumstances in which they were produced. When authored within industry or communication portfolios, strategies focus on broadband infrastructure, consumption and competitiveness, framed by the rubric of content (eg, Forfas, 2002). Strategies prepared with more active and substantial input from cultural agencies brings questions of access and preservation into view, structuring discussion around the concept of information (eg, Library and Archives Canada, 2007, Ministry of Economic Development, 2008). The Australian strategy falls within the former group.

\section{From Information Society to Digital Economy - Framing Australia's Strategy}

The development of a digital strategy in Australia - like comparable exercises elsewhere - has sources in debates over the role of information and knowledge in a post-industrial society, and developing concern over the citizenship and public service benefits accruing from e-government (Middleton, 1997). Public libraries featured prominently in emerging Australian debates. In addition to their broadly stated cultural and educational mandates, libraries have long publicised their role in economic development (McVilly, 1975, pp.18-20). This mission was reformatted and extended with the development of science and technology databases and electronic information networks (Balnaves and Biskup,1975, pp.172-177; Scientific and Technological Information Services Enquiry Committee, 1975; Jones, 1982; House of Representatives Standing Committee for Long Term Strategies, 1991). Interest in the information society was underpinned by spectacular growth predictions made in the mid-twentieth century for information as a commodity (Webster and Robins, 1986, p.329). Public libraries in Australia and elsewhere argued their case anew as reliable and accessible information repositories and expert instructors in information literacy 
(American Library Association Presidential Committee on Information Literacy, 1989).

Enthusiasm in Australia for the development of an information policy has been more apparent within social democratic Labor administrations than conservative Liberal ones. This can be explained by, amongst other things, the interests and intellectual force of senior Labor figure the Hon Barry Jones (Federal Minister for Science 1983-1990), and Liberal suspicion of the big-government connotations of information as a policy domain (Environment, Communications, Information Technology and the Arts References Committee, 2003, p.54). But the broad church of neo-liberalism comfortably accommodates its Australian variants of market liberalism, identified with conservative governments, and Labor's more interventionist commitment to social markets. The gradual shift in policy rhetoric from information society, through information economy, to digital economy points most obviously to the development and extension of digital technologies into many areas of economic and social life. It also indicates the evolving and converging ideological positions of alternative Australian governments.

The release of a wide-ranging cultural policy by the Keating Labor government in 1994 marked the first Australian attempt to fuse the cultural, economic and technical dimensions of digital communication technologies (Department of Communications and the Arts, 1994). Appearing six months after the public internet in Australia, the statement confidently predicted the arrival of contenthungry broadband as a significant opportunity and challenge for the Australian "cultural industry". In contrast to Keating's cultural program the subsequent Howard Liberal government (1996-2007) established a National Office for the Information Economy, and focussed on the online provision of government services (National Office of the Information Economy, 1998).

In 2004 the Howard government revised its framework to bring productivity and economic development issues to the fore (Department of Communication, Information Technology and the Arts, 2004). Industry and communications ministers commissioned a group of media and digital content industry representatives (none from public cultural agencies) to review the development of digital industries, producing Unlocking the Potential - Digital Content Industry Action Agenda in 2005 (Department of Communications, Information Technology and the Arts, 2005). Informing the document was a background study of creative industries in Australia, which identified high growth and economic multiplier characteristics of the sector, but raised concern that its competitors were outpacing Australia (p.16). Unlocking the Potential aspired to "...achieve a sustainable and internationally competitive Digital Content industry which doubles in value to $\$ 42$ billion by $2015 "$ ( $p .8)$. The report was especially concerned with structural issues, most notably broadband rollout, but also skills development, investment, intellectual property, technical standards, and export facilitation. The supply-side focus of Unlocking the Potential chimed with perceptions elsewhere within the Australian government of cultural institutions as "stockpiles of goods 
and services" (Prime Minister's Science, Engineering and Innovation Council, 2005 , p. 19). Supporting the report's focus on "product realisation" (p.29) was the establishment of a Digital Content Working Group to "...stimulate the supply and effective use of high quality and relevant Australian digital content that will drive demand for broadband services" (cited in Collections Council of Australia, 2007, p.11).

The 2007 federal election campaign saw the Rudd Labor opposition bring the internet - as campaign tool and policy objective - to the centre of its election strategy. Labor promised to equip Australian secondary school students with "the toolbox of the twenty-first century" (notebook computers) and roll out a new high speed broadband network (Australian Labor Party, 2007). The focus on broadband carried through to portfolio arrangements when Labor took office. The Department of Broadband, Communications and the Digital Economy, formerly the culture and communications ministry, was established as the first nominally economic portfolio outside the traditional treasury structure in the century-long history of Australian federal administration.

Future Directions defines the digital economy as "[t]he global network of economic and social activities that are enabled by information and communications technologies, such as the internet, mobile and sensor networks" (p.2). This definition is consistent with broad conceptions of an economy as a system of activity connected with the production, trade and consumption of goods and services (Black, 2009). Government, industry and the community are identified as the principal actors in a "market-led" digital economy, and instructed to work together in partnership to harness economic opportunities (p.ii). In this scenario, the government provides broadband infrastructure, a benign regulatory environment, and support for innovation. Industry is tasked with building its digital confidence and skills, adopting smart technology and developing sustainable content models. The economic agency of community is less obvious. Inclusive participation and media literacy skills and are nominated as key factors to enable community benefit from "online engagement" (p.iv).

Where Unlocking the Potential can be read as an industry statement, Future Directions aspires to "connect the dots" (p. ii) between policy documents spanning digital education, regional development, innovation, and intergovernmental co-ordination (Department of Innovation, Industry, Science and Research, 2009; Online and Communications Council, 2008). ICT policies, says the document, "are becoming less sector-specific and more part of the mainstream economic policies that concern the economy and society as a whole" (p.58). But the content-is-king message is still forcefully delivered. "Content is a significant draw for attracting Australians online and particularly in driving broadband adoption... relevant content will attract Australians online and...drive digital literacy" (p.35). Countries lacking a sustainable local content industry, says the document, are likely to suffer from low participation, lost investment, and a dilution of cultural identity. 


\section{Future Directions and Public Libraries}

With its breadth and orientation, it is unsurprising that Future Directions devotes minimal space to public libraries or other public cultural institutions. Public libraries are principally recognised in the document for their role in promoting digital literacy through internet access and training. For library commentators, this is an important (if often informal and underfunded) role for libraries (Harding, 2008, Missingham, 2009). It also dovetails with Future Directions' advocacy of freely available public sector information (PSI), a recommendation that was strongly argued by the Australian government's recent 'innovation' review (Cutler and Company, 2008).

However, the assumptions about public libraries and other cultural institutions in Australia's evolving digital strategy, rather than their explicit discussion, have caused disquiet. Future Directions echoes earlier instrumentalist views that build cultural institutions into broadband uptake and digital consumption. Following release of Unlocking the Potential, the intergovernmental advisory body on cultural collections, the Collections Council of Australia (CCA, formed 2004), expressed concern that policy initiatives on digital content "convey the sense that the collections sector is ready to resource emerging demands from other sectors for digital content" (Collections Council of Australia, 2007, p.10). There is little in Future Directions to indicate a change in this position.

The Australian library sector has not been a passive observer of digital developments. Behind free-wheeling discussion of investment in a digital future lies a history of re-organising Australian library budgets and activities to take advantage of emerging digital technologies and network environments. This activity is animated by a commitment to service innovation and economic efficiency, as well as ensuring basic provision of the "communicative entitlements" of citizenship (Scannell, 1989). The Australian library and archive sectors have been at the forefront of developments in web harvesting ${ }^{3}$, digital record keeping ${ }^{4}$ and resource sharing (Dempsey, 2006, pp.7-8). The formation in 2007 of Electronic Resources Australia (http://era.nla.gov.au/), a consortium for coordinating, purchasing and distributing online databases and information resources, is a recent iteration of a long-standing cooperative approach to collection development and access in the federal Australian library system. CCA, which includes library sector representation, argued that further coordinated national action was urgently needed to bring 'born digital' and 'made digital' collections together in a comprehensive management framework. The CCA report echoed the 'unlocking' theme in criticising fragmented digitising initiatives, but focussed on structural aspects of collection management and access to

\footnotetext{
${ }^{3}$ The National Library of Australia's PANDORA project commenced web harvesting in 1996, and currently preserves and makes available over 11,000 sites - www.pandora.nla.gov.au

${ }^{4}$ Public Records Office of Victoria, Victorian Electronic Records Strategy program http://xml.coverpages.org/ni2002-03-29-a.html
} 
digital collections rather than repeating the call for more digital content. Reinforcing these points in a submission on the consultation draft of Future Directions, CCA argued that lack of resources and restrictive regulatory structures hindered experimentation and innovation in the use of public collections and public sector information (Collections Council of Australia, 2009). The Australian Library and Information Association (ALIA, Australia's peak organisation of library professionals) and the Australian Digital Alliance (a consortium of public cultural and educational institutions) made similar points in their submissions ${ }^{5}$. As Lavoie et al $(2005$, p.1) argue, in an era of zero-sum budgeting, digital resources inevitably compete with print collections (and, we add, an expanding menu of public programs) for funds. Funding pressures are evident elsewhere too. News that CCA will be de-funded in 2010 will silence an important advocate for the collections sector. The mantra of investment running through Unlocking the Potential (it appears about twice per page) and, to a lesser degree Future Directions, is directed to 'the market'. The terms in which Australian governments are prepared to invest in public libraries to promote the social and economic benefits of digital information are less apparent .

\section{Living Within Their Means?}

The impact of digital technologies and the online information environment has been much debated by the library sector. Forecasts of library futures range from the imminent replacement of reference functions by commercial search engines (Taiga Forum Steering Committee, 2006) to the recreation of Alexandrian 'universal libraries' 6 . A middle position, articulated by the British Library (2005, p.3) and finding acceptance elsewhere, describes major public libraries as hybrid institutions, aiming for seamless information provision across media and storage locations. The British Library has recast its institutional framework from an ownership model, realised through legal deposit and collection development, to an access model, where the library serves as a gateway to digital content stored by public and private repositories. Partnerships with major software companies, especially around mass digitisation and storage, are seen as important vehicles for meeting library service commitments to provide access to information when and where users want (Joint Information Systems Committee, 2005, p.4; British Library, 2005).

Major public libraries have complex and sometimes competing mandates for cultural preservation, access and service provision, and resource efficiency. In fulfilling these mandates they strive to balance strategic (market- and resourceoriented) and prudential (public good oriented) considerations. Rather than engage with the diverse commentary on some more contentious digital library projects (for example see Dempsey, 2006; Kaufman and Ubois, 2007; Jeanennay, 2007; Leetaru 2008), we are interested in placing such

\footnotetext{
${ }^{5}$ http://www.dbcde.gov.au/digital_economy/future_directions_of_the_digital_economy/submission $\mathrm{s}$

${ }^{6}$ http://ec.europa.eu/information_society/activities/digital_libraries/index_en.htm
} 
developments within a longer, 'unquiet' history of libraries as institutions periodically buffeted by major cultural and technological changes (Battles, 2003). There is little dispute that we are witnessing the emergence of a new information landscape, characterised by hybrid institutional forms and evolving business models, and underpinned by high-capacity broadband. To what extent does Future Directions promote a supportive policy framework that will enable public libraries to fully 'engage' with this landscape?

One revealing feature of the British Library framework, mentioned above, is its determination to remodel within its existing level of public funding, arguing that private equity represents the only option to meet the challenges of the digital era. From the present vantage point, amidst the expenditure by Western world governments of billions of dollars to stimulate recessionary economies, this assumption about the limits of public investment is questionable. Rather, such statements mark out the limits of welfare economics - the boundary at which governments are prepared to fund libraries and other cultural institutions as public goods. Viewing libraries from this market failure perspective seems increasingly discordant with the 'innovation agenda' of Australian and other Western world governments. Potts et al. (2008), arguing from a Schumpeterian and evolutionary perspective, call for recognition of innovation and knowledge growth as the engine of economic growth. Such a view, they argue, "might provide a better foundation for cultural and creative industries policy than the implicit extant basis in market failure and social welfare arguments" (p.182). Similarly, the Cutler innovation review $(2008$, p.98) argued that "funding models and institutional mandates should recognise the research and innovation role and contributions of cultural agencies and institutions responsible for information repositories, physical collections or creative content and fund them accordingly". This recommendation received no mention in the Australian government's response to Cutler (Department of Innovation, Industry, Science and Research, 2009), nor in the enthusiastic discussion of innovation in Future Directions.

This perspective also assists in critically evaluating Future Directions' conception of 'community'. Future Directions associates 'community' with normative goals of empowerment and participation, while making little attempt to explore the potential and limitations of these concepts. The meanings are largely framed in terms of social equity, with policy action centred on closing the digital divide. However, during the few years covered by this analysis the theoretical and empirical framing of community as a locus of production has developed significantly. This has been encouraged by cultural, technological, commercial and regulatory developments that receive some acknowledgement in more recent national digital strategies (eg, Ministry of Economic Development, 2008). Future Directions (p.13) discusses the re-use and innovation that flows from placing public cultural collections in open source environments, citing the pioneering use by Australian institutions of the Flickr image platform (www.flickr.org). Perhaps a more potent example for our purposes, not mentioned by Future Directions, is the large-scale Australian Newspapers 
Digitisation Project ${ }^{7}$. This National Library of Australia-led project organises several thousand online volunteers on several continents to correct errors from the digitisation of nineteenth century newspapers. Despite suspicion of library motives in this field (Baker 2001), it is unlikely that such a project would see the light of day were it not for the internet's low transaction costs and public goodwill towards libraries. The analogy of the library as a quarry to be mined for digital resources has its limits. Public libraries are also innovators and producers in the digital economy.

\section{Consumers and Citizens}

As public libraries explore their role in cultural and economic settings driven by huge bandwidth increases and enhanced digital applications, continued discussion is needed about the consequences of shifting not simply from analogue to digital media, but from print to digital culture. A new information landscape, characterised by the distributed nature of digital records, the increasingly commercial focus on intellectual property, and low entry costs for cultural production, requires new thinking about digital resource management, information competencies, and public access. For some, libraries are largely bypassed in this environment, in a downward role shift to individuals:

...online services offer massive data and information collections that surpass any traditional library source. The skill sets of citizens will change - citizens will need to know where to find information quickly, how to absorb that information, and how to assess its reliability and use in a timely and well-articulated fashion. (OECD, 2006b, p. 8)

A contrasting institutional perspective is offered by the Library of Congress: (2002, p. 1)

[n]ever has access to information that is authentic, reliable and complete been more important, and never has the capacity of libraries and other heritage institutions to guarantee that access been in greater jeopardy.

A contrast, certainly; but there is also an important intersection here between two different, and in their own ways entirely conventional, policy languages. Both the Library of Congress and the OECD are seeking to describe not only the attributes of the future information economy, but also the dispositions of future digital citizens. While the OECD sees these as a question of human capital formation, where the user's capacity to assess the reliability of information is an emerging and necessary civic competency, the Library of Congress presents information quality - reliability, authenticity and completeness - as a public, institutional mandate, a necessary service for citizens. The evidence in this area underlines the gap in public confidence surrounding the digital economy, suggesting that both perspectives may be necessary, and that the sanguine tone of Future

\footnotetext{
${ }^{7}$ http://www.nla.gov.au/ndp/
} 
Directions' observations on "digital confidence" may be misplaced. We have already noted how substantial public resources are now being committed in Australia to the construction of a major new public broadband network; similar commitments in kind if not in magnitude are proposed in the United Kingdom and other countries. There appears to be considerable support for such initiatives, and broadband uptake continues to grow in all countries. But at the same time, people continue to express significant reservations about the integrity of the information available on the Internet, and there continues to be a difference between the views of Internet users and non-users. Recent Australian research found that eighty-four per cent of users (84.1\%) thought that at least half of the information on the web was reliable (78.4\% in 2007) compared to just under six in ten non-users (59.3\% up from 51.0\%) (Ewing and Thomas, 2010).

Reservations about information reliability are likely to be connected with concerns about e-commerce, messaging and other services.

Future Directions does not set out to deal specifically with the ontology of digital media or the changing role of public libraries. But as we have argued, its focus on a particular reading of the digital economy would limit its capacity to undertake such a task. Future Directions' attention is directed to developing a market for broadband consumption of both private and public goods. This is a structural transformation that will have a major impact on public libraries and the Australian cultural sector generally. The Australian library sector has begun to assess the implications of Future Directions and related policies addressing the digital environment (Missingham, 2009). Assisting this exercise are some cogent responses by the library sectors of other countries to digital strategies produced in those jurisdictions (National Library of New Zealand, 2008). A threshold question in shaping library responses is whether the framing concept of a digital economic strategy will reflect and support the complex mandates of public libraries. Future planning in a field characterised by non-linear change is hazardous, and Australia's record in implementing high level sectoral strategies is patchy. Some of the case studies presented in Future Directions reflect the beneficial results of long term policy directions or major investments; others are notable for the highly circumstantial or coincidental nature of their outcomes. The development in Australia of Google Maps, for instance, is an icon of the transformative power of local digital innovation, and is repeatedly celebrated in the document. Of course Google Maps is now an important part of the global digital economic infrastructure. As the case study explains, it is almost completely coincidental that it emerged in Sydney: one of the lead developers relocated to Australia from the United States because his partner happened to be Cuban; the other also had a US visa problem after he lost a job in the tech wreck of 2001.

\section{Re-valuing Public Libraries}

Despite its forward-looking posture, Future Directions' description of content resembles an older model of the Australian economy, dependent on resource extraction and characterised by concentrated media and entertainment sectors. 
That model has been frequently criticized for its limited attention to eco-system values, economic diversification, and information pluralism, warning us against its replication in the digital economy. But Future Directions' content-is-king emphasis suggests a path dependence that challenges us to think about alternative policy directions - and value arguments - for public libraries.

The ecological or environmental metaphor used by Nardi and O'Day (1999), amongst others, provides a powerful way of imagining future library roles, although not one that will necessarily comfort library traditionalists. An ecological or holistic approach is well established in the social sciences as a way of understanding system-level influences, interdependencies and constraints on activities and institutions, and promoting ethical and institutional principles to enhance sustainability and resource-sharing.

Change and resilience are underlying characteristics of healthy eco-systems, and libraries are certainly confronted with major changes in the nature of information media, forms of access, and user relationships. In appraising the impact of digital technologies on libraries, Nardi and O'Day (p. 82) argue that a classic ecological pattern of invasion and succession is all too possible. They argue instead for mutual adaptation and the fostering of new relationships between technology, policy and practice.

In our view an alternative policy agenda to that sketched by Future Directions, resting on an ecological rather than a strategic markets view, involves articulating the role and value of public libraries in two broad and related areas.

The first is the constitution, preservation and uses of cultural memory - the decisions libraries make about what to collect and preserve, and the terms under which the collection can be accessed. In the physical realm, access and preservation tend to pull in opposite directions, as recognised by distinctive institutional mandates (libraries prioritising access, archives preservation). Digitisation can reduce this tension, assisting preservation, widening access and mitigating sharp criticisms of accessionism levelled by economists against public cultural institutions (eg, Peacock 1998). However, long-standing concern in Australia with the management of physical collections, has, as we have seen, been echoed in criticism of digital archiving. The reproducibility of digital files is no guarantee of either preservation or access. For some critics it signals fragility, for others, information chaos. Concerns over the institutional and technological barriers to digital archives have found inventive responses in initiatives such as the LOCKSS project of dispersed storage in trusted public domain repositories (www.lockss.org/). However, recent discussions of the internet as a domain of surveillance and discipline have questioned permanent digital preservation as unequivocally good, mounting arguments for digital decay or deletion that replicate human forgetting (Laermans and Gielen 2007, Mayer-Schonberger 2009). This is a complex and rapidly evolving domain of policy and practice that engages profound cultural and political questions. In this regard, Nardi and O'Day's anthropogenic focus on librarians, whom they hold to be the Wilsonian 
'key species' of a healthy information ecology, is well placed. Here, it is important to move discussion beyond 'the library' to librarians as information specialists capable of analysing information trends and designing appropriate institutional responses. The cultural and political ramifications of information in digital form require new thinking beyond the transactional framework of the digital economy, and about the role and skills of librarians.

The second area is the role of public libraries in promoting digital literacy, including skills of critical evaluation, and providing access to open source platforms and tools. Future Directions discusses "digital media literacy" as a prerequisite for the evaluation, consumption and creation of digital media. The document's attention to schools as literacy providers is not matched by a focus on the major institution of the informal education sector - the public library. Yet as Harding (2008) concluded from an international survey of digital literacy initiatives in public libraries, this role has often been seen as an "imposed responsibility" on often ill-equipped librarians and libraries. As social and economic activity, information and public services migrate to the internet, the costs of disadvantage in this area are magnified. That said, digital literacy is not a self-evident concept. Its application may range from basic technological competency through to high order skills of content evaluation and creation. Policy, professional, and physical (building) constraints have limited mobilisation of the library network as a centrepiece of digital initiatives. However, with the spread of Web 2.0 technologies, the peak sectoral body National and State Libraries Australasia (NSLA) has nominated the development of frameworks and tools to enable "community created content" as a major strategic goal (NSLA, 2008). In this light, securing favourable access to NBN capabilities, to provide a public digital space and open source platforms for experimentation and civic initiatives, may significantly advance NSLA's ambitions.

During the 1990s, Australian public libraries and other public collecting institutions were engaged in lengthy discussions with governments over a mandate to value their collections. The narrow financial construction of value, and the falling away of government interest once that task was accomplished, was a source of frustration for many in the sector. We argue that the discussion should be revived at this significant policy moment. Future Directions underplays the value of public libraries and librarians in the information ecology. This value accrues from their stewardship of cultural resources (physical and digital), their services in analysing and designing new institutional responses for the management of digital information, and their role in providing open source alternatives to proprietary media. However, even in its own terms, Future Directions' focus on SMEs underplays the value of social enterprise, realised through the social capital built through collaborative endeavours, and through the future markets flowing from innovations in the non-market or community sphere. In the digital environment, major public libraries, in particular, can provide institutional support for such enterprises. To leverage the investment rhetoric of Future Directions, we argue, public libraries need to restate their value in the 
broad terms outlined above. Whether Future Directions, and the policy framework that emerges from it, can support such claims in a new broadband landscape is a question of vital interest to public libraries and digital citizens alike.

\section{Concluding Remarks}

Coinciding with the Australian government's announcement of major investment in broadband infrastructure, Future Directions creates an important space for debate and policy formation that extends well beyond the now conventional parameters of cultural and information policy. However, if the Australian government sought to grapple with the complex economic, social and cultural implications of digital technologies, the logic of strategy - as a reflexive and competitive response - prioritised the economic component.

As we have argued, this stance has significant implications for major public libraries. The strategic emphasis on broadband infrastructure and entrepreneurship has created a climate of expectations surrounding major libraries in which extended access is hinged with private investment, and concern for the production of digital content is disconnected from the management of physical and digital collections. Several industry-focussed national digital strategies have drawn responses from the library sectors of those countries seeking to illuminate these issues, and reinforce the complexity of policy development in the digital domain. Business commentary has suggested that the recent crisis in financial markets heightens the realisation that digital technologies and industries are the new economic drivers (Chapman, 2008). However, the crisis exposed hubristic growth projections in the digital economy (Bayliss, 2007), and brought a reappraisal of existing internet business models, especially for media companies. The development of open source platforms for public sector information and cultural collections confounds simple binaries that the private market sector is the source of wealth generation and innovation, and the public cultural sector requires market failure and social welfare rationales for support. The Australian library sector's actions in the field of digital technologies have had a practical emphasis, through the development of digitisation, web harvesting, resource sharing and open content initiatives. We suggest that Future Directions now warrants a substantial philosophical and policy-oriented response.

\section{References}

American Library Association Presidential Committee on Information Literacy (1989) Final Report, Chicago, American Library Association.

Australian Labor Party (2007) A Digital Education Revolution - Election 2007 Policy Document, available from

http://www.alp.org.au/download/now/labors digital education revolution campaign launch.pdf [accessed December 2009].

Balnaves, J. and Biskup, P. (1975) Australian Libraries, $2^{\text {nd }}$ Ed, London, Clive Bingley. 
Baker, N. (2001) Doublefold - Libraries and the Assault on Paper, New York, Random House.

Battles, M. (2003) Libraries - An Unquiet History, New York, Norton.

Bayliss, D. (2007) 'Dublin's Digital Hub - Lessons from an Attempt to Develop a Creative Industry Cluster', European Planning Studies, 5, 9, pp.1261-1271.

Black, J. (2009) A Dictionary of Economics, Oxford Reference Online, Oxford University Press, available from

http://www.oxfordreference.com/views/ENTRY.html?subview=Main\&entry=t19.e944, [accessed

August 2009].

British Library (2005) Redefining the Library - The British Library's Strategy 2005-2008, available from http://www.bl.uk/aboutus/stratpolprog/strategy0811/blstrategy20052008.pdf [accessed December 2009].

Cawley, A. and Preston, P. (2007) 'Broadband Content and Digital 'Content' in the EU-25: Recent Trends and Challenges', Telematics and Informatics, 24, pp. 259-271.

Chapman, D. (2008) 'NZIM Digital Strategy - Why Managers Should Care', New Zealand Management, 55, 5, p. 24.

Collections Council of Australia (2007) Australian Framework and Action Plan for Digital Heritage Collections, available from

http://www.collectionscouncil.com.au/Portals/O/Australian\%20Framework\%20and\%20Action\%20 Plan\%20for\%20DHC Version\%200.C3.pdf [accessed December 2009].

Collections Council of Australia (2009) Response to Digital Economy Future Directions Consultation Paper, available from

http://www.dbcde.gov.au/digital economy/future directions of the digital economy/submissions [accessed December 2009].

Commission of the European Communities (2005) i2010 - A European Information Society for Growth and Employment, available from http://eur-lex.europa.eu/LexUriServ/LexUriServ.do?uri=COM:2005:0229:FIN:EN:PDF [accessed December 2009].

Conroy, Senator the Hon Stephen, Minister for Broadband, Communications and the Digital Economy (2009) New National Broadband Network - Media Release 7 April 2009, available from http://www.minister.dbcde.gov.au/media/media releases/2009/022 [accessed August 2009].

Cutler and Company (2008) venturousaustralia - Review of the National Innovation System, Melbourne, Cutler and Company.

Dempsey, L. (2006) 'Libraries and the Long Tail - Some Thoughts about Libraries in a Network Age', D-Lib Magazine, 12, 4, pp. 7-8.

Department of Broadband, Communications and the Digital Economy (2009) Digital Economy Future Directions, Canberra, Commonwealth of Australia, available from http://www.dbcde.gov.au/ data/assets/pdf file/0006/117681/DIGITAL ECONOMY FUTURE DI RECTIONS FINAL REPORT.pdf [accessed August 2009].

Department of Communications and the Arts (1994) Creative Nation - Commonwealth Cultural Policy, Canberra, Commonwealth of Australia. 
Department of Communication, Information Technologies and the Arts (2004) Australia's Strategic Framework for the Information Economy 2004-2006, Canberra, Commonwealth of Australia.

Department of Communications, Information Technology and the Arts (2005) Unlocking the Potential - Digital Content Industry Action Agenda - Strategic Industry Leaders Group Report to the Australian Government,

http://archive.dcita.gov.au/ data/assets/pdf file/0006/37356/06030055 REPORT.pdf [accessed December 2009].

Department of Innovation, Industry, Science and Research (2009) Powering Ideas - An Innovation Agenda for the $21^{\text {st }}$ Century (Canberra, Commonwealth of Australia) http://www.innovation.gov.au/innovationreview/Documents/Poweringldeas fullreport.pdf [accessed December 2009].

Environment, Communications, Information Technology and Arts References Committee, Senate of the Parliament of Australia (2003) Libraries and the Online Environment, available from http://www.aph.gov.au/Senate/committee/ecita ctte/completed inquiries/200204/online libraries/report/report.pdf [accessed December 2009].

Ewing, S. and Thomas, J. (2010) CCI Digital Futures: The Internet in Australia 2010 (ARC Centre for Creative Industries and Innovation, Brisbane).

Forfas (2002) A Strategy for the Digital Content Industry in Ireland, available from http://www.forfas.ie/media/forfas021101c digital content strategy.pdf [accessed December 2009].

Given, J. (2008) 'The Eclipse of the Universal Service Obligation - Taking Broadband to Australians', Info 10, 5/6), pp. 92-106.

Harding, A. (2008) 'Information Literacy - We've Walked the Walk but are We Talking the Talk?', Australian Library Journal, 43, 3, pp. 274-294.

House of Representatives Standing Committee for Long Term Strategies (1991) Australia as an Information Society - the Role of Libraries/Information Networks, Canberra, Commonwealth of Australia.

Jeannenay, J. (translator T. Fagen) (2007) Google and the Myth of Universal Knowledge, Chicago, University of Chicago Press.

Joint Information Systems Committee (2005) Digitisation in the UK - the Case for a UK Framework, available from http://www.jisc.ac.uk/uploaded documents/JISC-Digi-in-UK-v1final.pdf [accessed December 2009].

Jones, B. (1982) Sleepers, Wake! Technology and the Future of Work, Oxford University Press, Melbourne.

Kaufman, P. and Ubois, J. (2007) 'Good Terms - Improving Commercial-Noncommercial Partnerships for Mass Digitization', D-Lib Magazine, 13,12, http://www.dlib.org/dlib/november07/kaufman/11kaufman.html

Klein, H. (2004) 'Understanding WSIS - An Institutional Analysis of the UN World Summit on the Information Society', Information Technologies and International Development, 1, 3-4, pp. 3-13. 
Laerman, R. and Gielen, P. (2007) 'The Archive of the Digital An-archive', Image and Narrative, 17, April 2007, www.imageandnarrative. be/digital archive/laermans gielen.htm

Lavoie, B., Connaway, L. and Dempsey, L. (2005) 'Anatomy of Aggregate Collections - the Example of Google Print for Libraries', D-Lib Magazine, 11(9),

http://www.dlib.org/dlib/september05/09contents.html

Leetaru, K. (2008) 'Mass Book Digitization - The Deeper Story of Google Books and the Open Content Alliance', First Monday, 13,10,

http://firstmonday.org/htbin/cgiwrap/bin/ojs/index.php/fm/article/view/2101/2037

Library and Archives Canada (2007) Canadian Digital Information Strategy - Draft Consultation Version, available from http://www.collectionscanada.gc.ca/obj/012033/f2/012033-1000-e.pdf [accessed December 2009].

Library of Congress (2002) Preserving our Digital Heritage - A Plan for the National Digital Information Infrastructure and Preservation Plan, available from http://www.digitalpreservation.gov/library/resources/pubs/docs/ndiipp plan.pdf [accessed December 2009].

Mayer-Schonberger, V. (2009) Delete - The Virtues of Forgetting in the Internet Age, Princeton University Press, Woodstock NJ.

McDonald, J. (2006) Towards a Canadian Digital Information Strategy - A Review of Relevant International Initiatives (Library and Archives Canada, Ottawa), available from http://collectionscanada.ca/obj/012033/f2/012033-800-e.pdf [accessed December 2009].

McVilly, D. (1976) A History of the State Library of Victoria 1853-1974, M.A. thesis, Monash University, pp. 18-20.

Middleton, M. (1997) 'Information Policy and Infrastructure in Australia', Journal of Government Information, 24,1, pp. 9-25.

Ministry of Economic Development (2008) The Digital Strategy 2.0 - Creating our Digital Future, available from www.digitalstrategy.govt.nz [accessed December 2009].

Ministry of Modernisation (2005) eNorway 2009 - the Digital Leap, available from http://www.regjeringen.no/upload/FAD/Vedlegg//KT-politikk/eNorway 2009.pdf [accessed December 2009].

Missingham, R. (2009) 'Encouraging the Digital Economy and Digital Citizenship', ALIA Public Libraries Summit, Canberra, July 2009, available from http://www.alia.org.au/governance/committees/public.libraries/summit09/ [accessed December 2009].

Nardi, B. and O'Day V. (2006) Information Ecologies - Using Technologies with Heart, MIT Press, Cambridge MA and London.

National Library of New Zealand (2007) Creating a Digital New Zealand - New Zealand Digital Content Strategy (National Library of New Zealand, Wellington), available from http://www.digitalstrategy.govt.nz/upload/Main\%20Sections/Content/NATLIBDigitalContentStrate gy.pdf [accessed February 2009].

National Office of the Information Economy (1998) A Strategic Framework for the Information Economy, Commonwealth of Australia, Canberra. 
National and State Libraries Australasia (2006): Libraries in the Digital Environment, available from http://www.nsla.org.au/publications/papers/ [accessed December 2009].

National and State Libraries Australasia (2007) The Big Bang - Creating the New Library

Universe, available from http://www.nsla.org.au/publications/papers/ [accessed December 2009].

National and State Libraries Australasia (2008) Re-imagining Library Services,

available from http://www.nsla.org.au/projects/rls/ [accessed March 2010].

Online and Communications Council (2008) Framework for the Collaborative Development and Use of Broadband in Australia, available from

http://www.occ.gov.au/ data/assets/pdf file/0018/13716/0051001001 NBDG BROCH WEB.pd f [accessed December 2009].

Organisation for Economic Cooperation and Development Working Party on the Information Economy (2006a) Digital Broadband Content - Digital Content Strategies and Policies, available from www.oecd.org/sti/digitalcontent [accessed December 2009].

Organisation for Economic Cooperation and Development Working Party on the Information Economy (2006b) The Future Digital Economy - Digital Content, Creation, Distribution and Access - Conference Summary, available from www.oecd.org/dataoecd/48/30/37046422.pdf [accessed December 2009].

Peacock, A. (Ed.) (1998) Does the Past Have a Future? The Political Economy of Heritage London, Institute for Public Affairs.

Potts, J., Cunningham, S., Hartley, J. and Ormerod, P. (2008) 'Social Network Markets - a New Definition of the Creative Industries', Journal of Cultural Economics, 32, pp.167-185.

Prime Minister's Science, Engineering and Innovation Council (2005) Imagine Australia - The Role of Creativity in the Information Economy, available at http://www.dest.gov.au/NR/rdonlyres/B1EF82EF-08D5-427E-B7E4-

69D41C61D495/8625/finalPMSEICReport WEBversion.pdf [accessed December 2009]

Pyati, A. (2005) 'WSIS - Whose Vision of an Information Society?', First Monday, 10, 5, available at http://www.uic.edu/htbin/cgiwrap/bin/ojs/index.php/fm/article/view/1241/1161.

Scannell, P. (1989) 'Public Service Broadcasting and Modern Public Life', Media, Culture and Society, 11, 2, pp.135-166.

Scientific and Technological Information Services Enquiry Committee (1975) The STISIC Report, National Library of Australia, Canberra.

TAIGA Forum Steering Committee (2006) TAIGA Forum Provocative Statements, http://www.taigaforum.org/documents/ProvocativeStatements.pdf [accessed December 2009].

Webster, F. and Robins, K. (1986) Information Technology - A Luddite Analysis, Ablex Publishing Corporation, Norwood NJ.

Weiss, L., Thurbon, E. and Mathews, J. (2004) How to Kill a Country - Australia's Devastating Trade Deal with the United States, Allen and Unwin, Sydney.

WSIS Executive Secretariat (2005) Report on the WSIS Stocktaking, 19 October 2005, available at http://www.itu.int/wsis/docs2/tunis/off/5.pdf, [accessed December 2009]. 
Yanow, D. and Schwart-Shea, P. (2006) Interpretation and Methods - Empirical Research Methods and the Interpretive Turn, ME Sharpe, Armonk NY. 